\title{
Makna corporate social responsibility (CSR) pada PT. Sejahtera Usaha bersama Jombang
}

\author{
David Amrulloh, Sulastri* \\ Universitas Negeri Malang, Jl. Semarang No. 5 Malang, Jawa Timur, Indonesia \\ *Penulis korespondensi, Surel: sulastri.fe@um.ac.id
}

Paper received: 1-4-2021; revised: 22-4-2021; accepted: 29-4-2021

\begin{abstract}
Corporate Social Responsibility (CSR) is a business commitment to act ethically, operate legally, contribute to economic improvement and improve the quality of life of stakeholders. In the modern era, the priority is no longer the property of shareholders, but the welfare of the stakeholders is a responsibility prioritized by the company. The emergence of Law No. 40 of 2007 concerning Limited Liability Company (UUPT) and Law No.25 of 2007 concerning Investment (UUPM) marked the commencement of CSR arrangements in Indonesia. The concept of CSR contained in the UUPM and UUPT will be seen in PT. Sejahtera Usaha Bersama Jombang. As a private company that engaged in industry, especially plywood. This study aims to uncover the meaning of Corporate Social Responsibility (CSR) from the point of view of the management of PT.SUB in- depth and comprehensively. This type of research is qualitative with phenomenology method and uses Husserl's data analysis techniques, with epoche stages, phenomenological reduction, imagination variations, synthesis of meaning and essence. Data collection in this study uses the method of observation, interviews, and documentation. Interviews are conducted in depth to explore individual awareness with semi-structured questions. The results of this study found two perspectives on the meaning of CSR at PT. SUB Jombang. First, CSR is defined as an obligation that is in the form of compliance with regulations. Second, CSR is interpreted as awareness, namely in the form of awareness of the company growing and developing in the midst of the community environment, and the realization that CSR is a charity and shodaqoh.
\end{abstract}

Keywords: Corporate Social Responsibility (CSR); obligations; awareness

\begin{abstract}
Abstrak
Corporate Social Responsibility (Tanggung jawab sosial perusahaan/CSR) merupakan sebuah komitmen bisnis untuk selalu bertindak sesuai etika, beroperasi mematuhi hukum, serta berkontribusi terhadap perkembangan ekonomi dan perbaikan kualitas hidup para aktor terkait. Di era modern, perusahaan tidak lagi memprioritaskan kekayaan dari para pemegang saham, tetapi perusahaan lebih bertanggung jawab atas kesejahteraan para pemilik saham. Diterbitkannya Undang-Undang No. 40 tahun 2007 tentang Undang-Undang Perseroan Terbatas (UUPT) dan Undang-Undang No. 25 Tahun 2007 tentang Undang-Undang Penanaman Modal telah menjadi awal tatanan CSR di Indonesia. Penelitian ini menyelidiki praktik pelaksanaan konsep CSR yang dijelaskan di dalam UUPM dan UUPT pada PT. Sejahtera Usaha Bersama (SUB) Jombang, sebuah perusahaan swasta di bidang kayu lapis. Penelitian ini bertujuan untuk mengetahui makna CSR, dari sudut pandang pihak pengelola PT SUB secara mendalam dan menyeluruh. Penelitian ini merupakan penelitian kualitatif dengan metode fenomenologi dan metode analisa data Husserl's, yang terdiri dari tahap epoche, reduksi fenomenologis, variasi imajinasi, serta sintesis makna dan esensi. DI dalam proses pengumpulan data, penelitian ini menggunakan metode observasi, wawancara, dan dokumentasi. Wawancara dilaksanakan secara mendalam untuk mengetahui kesadaran individu dengan pertanyaan semi terstruktur. Hasil dari penelitian menunjukkan adanya dua sudut pandang mengenai arti dari CSR dari PT. SUB Jombang. Sudut pandang pertama mengartikan CSR sebagai keharusan untuk patuh terhadap peraturan. Sedangkan sudut pandang kedua mengartikan Csr sebagai kesadaran dari perusahaan untuk tumbuh dan berkembang di tengah komunitas yang peduli akan lingkungan dan diwujudkan dalam bentuk amal dan sedekah.
\end{abstract}

Kata kunci: Corporate Social Responsibility; kewajiban; kesadaran 


\section{Pendahuluan}

Eksistensi perusahaan tidak dapat dipisahkan dengan masyarakat dan lingkungan. Terdapat hubungan timbal balik antara perusahaan dengan masyarakat. Perusahaan, masyarakat dan lingkungan adalah pasangan yang saling memberi dan membutuhkan. Kontribusi dan keharmonisan keduanya akan menentukan keberhasilan perusahaan itu sendiri. Hal ini yang menjadi salah satu alasan perlunya kesadaran terhadap tanggung jawab sosial atau bisa disebut Corporate Social Responsibility (CSR) demi tercapainya sebuah keseimbangan dunia usaha antara pelaku dan masyarakat sekitar yang menuntut para pelaku bisnis untuk menjalankan usahanya dengan semakin bertanggung jawab.

Pemerintah Indonesia menetapkan beberapa regulasi yang menitikberatkan pada konsep CSR sebagai sebuah kewajiban yang harus dilaksanakan oleh seluruh korporasi di Indonesia. Salah satu sektor perusahaan di Indonesia adalah sektor manufaktur dimana sektor ini memiliki dampak besar terhadap lingkungan sekitar karena dari proses operasional perusahaan manufaktur biasanya lebih banyak efek negatif terhadap lingkungan, hal ini dapat menambah kerusakan lingkungan eksternal perusahaan. Kebijakan terkait kebijakan lingkungan dan konservasi alam yang tertuang dalam Undang-undang No 23 Tahun 1997 tentang pengelolaan lingkungan hidup, pemerintah telah menetapkan bahwa perusahaan yang telah mengakibatkan pencemaran lingkungan atau perusakan lingkungan akan dikenakan sanksi berupa pidana dan denda atas perbuatannya. Sedangkan di Undang-Undang No 40 Tahun 2007 tentang Perseroan Terbatas menekankan bahwa setiap korporasi yang menggunakan sumber daya alam sebagai bahan baku utama wajib melaksanakan Tanggung Jawab Sosial (CSR). Selain itu, sesuai dengan pasal 74 UU Nomor 40 Tahun 2007 tentang Perseroan Terbatas, kewajiban soal pemberian CSR tersebut hanya terbatas pada perseroan atau perusahaan yang kegiatan usahanya berkaitan dengan sumber daya alam. Undangundang No 25 Tahun 2007 tentang Penanaman Modal, dan PP 47 Tahun 2012 tentang tanggung jawab sosial dan lingkungan perseroan terbatas, Menurut Coghill (1999) dalam Pujiningsih (2008), regulasi pemerintah dapat dipahami sebagai bagian yang tidak dapat dipisahkan dari lingkungan perusahaan, sebab sebagai badan pembuat aturan (Regulator Body) pemerintah memiliki peran signifikan terhadap kebijakan yang dibuat oleh perusahaan terhadap lingkungan eksternalnya.

Pada perusahaan PT.Sejahtera Usaha Bersama (SUB) Jombang yang turut memfokuskan tujuan dari keseluruhan aktivitas bisnisnya yaitu dengan memaksimalkan laba. PT.SUB Jombang yang berada dibawa naungan SAMKO TIMBER GROUPS, Tbk sejak 1979, dimana ada 6 unit pabrik di Indonesia, dan PT.SUB Jombang ini adalah pabrik yang ke 6. Perusahaan ini bergerak dalam bidang industri pengolahan kayu (Plywood) merupakan pabrik pengolahan kayu terbesar di wilayah Jombang. Sebagai perusahaan industri, PT.SUB Jombang wajib melakukan program CSR berdasarkan Undang-Undang No 40 Tahun 2007 dan pasal 74 UU Nomor 40 Tahun 2007, Undang-undang No 25 Tahun 2007 tentang Penanaman Modal, dan PP 47 Tahun 2012 tentang tanggung jawab sosial dan lingkungan perseroan terbatas.

PT SUB Jombang melaksanakan Program-program CSR pada beberapa jenis kegiatan, yaitu (1) Penyerapan tenaga kerja lokal di wilayah sekitar perusahaan adalah 200-300 orang, sedangkan untuk total penyerapan di wilayah Jombang sebanyak 2.701 orang. (2) Perbaikan sarana prasarana penunjang transportasi serta fasilitas fisik, dengan jumlah total bantuan dana tahun 2009- 2014 sebesar Rp 4.098.630.109. (3) Bantuan dana untuk peringatan hari besar nasional maupun keagamaan. Dengan alokasi dana dari tahun 2007-2016 mencapai Rp 
823.341.500. (4) Bantuan bibit pohon dan alat pertanian, dengan bantuan total dana dari tahun 2007-2016 sebesar RP 4.130.589.134. (5) Bantuan beasiswa dan orang tua asuh dari tahun 2007-2016 sebesar Rp 708.000.000. (6) Pemanfaatan limbah padat bukan B3. Pembuangan limbah padat yang dilakukan

perusahaan sebenarnya dapat mengganggu lingkungan utamanya saluran air yang berada tidak jauh dari lokasi pembuangan, namun limbah padat terutama kulit kayu banyak dimanfaatkan oleh beberapa produsen tahu dan kerupuk sebagai bahan bakar. Dengan adanya kulit kayu ini para produsen dapat menekan biaya produksi mereka. Karena kulit kayu ini diberikan secara gratis. (7) Adanya kerja sama antar perusahaan dengan masyarakat sekitar perusahaan. program ini bisa dibilang merupakan pemberdayaan yang melibatkan dan menyerap banyak tenaga kerja, terutama ibu rumah tangga yang menganggur atau memiliki banyak waktu luang. Pemberdayaan oleh PT SUB untuk mengolah atau mengelem triplek yang sobek/rusak, dan itu karena per lembar kayu lapis yang telah siap diproses ke tahap selanjutnya oleh pabrik dihargai oleh PT SUB sebesar Rp 200-300/lembar, sedangkan masyarakat bisa menghasilkan minimal 100-150/lembar. Jadi, pendapatan minimal masyarakat yang tergabung dalam program ini paling sedikit antara Rp. 600.000 sampai Rp. 1.350.000 tiap bulan. Dengan adanya perusahaan PT SUB ini masyarakat sekitar perusahaan juga mendapatkan dampak yang positif, seperti pertumbuhan ekonomi di sekitar perusahaan yaitu ditandai dengan banyaknya masyarakat yang beralih profesi dan munculnya usaha-usaha baru seperti masyarakat yang dulunya bertani kemudian membuka toko dan warung serta beberapa rumah makan, dibukanya tempat kos bagi para pekerja pabrik yang bertempat tinggal jauh dari lokasi perusahaan, ini tentu saja tidak lepas dari pendirian pabrik tersebut dimana sebagian besar pelanggan mereka adalah para karyawan dan pegawai pabrik tersebut.

Berdasarkan temuan pada pernyataan Bapak Deddy yaitu penerapan CSR merupakan kepatuhan perusahaan kepada peraturan pemerintah melalui Undang- Undang yang ada. Berdasarkan pernyataan tersebut muncul ide pokok dari teori institusional bahwa organisasi dibentuk oleh lingkungan institusional yang mengitarinya dan dengan begitu pengamatan atas organisasi harus dilihat sebagai sebuah totalitas simbol, bahasa, ataupun ritual-ritual yang melingkupinya (Skelley, 2002) dalam (Gudono, 2014). Jadi perusahaan mematuhi peraturan pemerintah karena perusahaan terbentuk atas dasar institusi pemerintah sehingga perlu mematuhi peraturan yang mendasarinya. Adapun hasil penelitian yang mendukung pernyataan tersebut Steinmo (2001) dalam Gudono (2014) menyatakan Institusionalisme Baru (New Institutionalism) mengkaji pengaruh besar institusi terhadap perilaku manusia melalui aturan-aturan dan norma yang dibangun oleh institusi. Institusi meliputi misalnya angkatan bersenjata, kantor kecamatan, pernikahan, asuransi, kode etik profesi, kelompok gang, pasar, perusahaan, dan masyarakat sebuah kampung.

Ditemukan juga pada pernyataan Bapak Deddy yaitu adanya kesadaran bahwa perusahaan hadir ditengah-tengah masyarakat sehingga dampak yang dihasilkan dalam kegiatan operasional perusahaan akan dialami oleh masyarakat secara langsung maupun tidak langsung, sehingga masyarakat perlu diperhatikan secara khusus dan diprioritaskan. Dari pernyataan tersebut dapat disimpulkan bahwa perusahaan memprioritaskan dan memperhatikan secara khusus masyarakat sekitar perusahaan. Sehingga masyarakat merasa nyaman akan hadirnya perusahaan di tengah-tengah masyarakat dan perusahaan bisa beroperasi secara produktif tanpa adanya protes dari masyarakat sekitar perusahaan. Pada pernyataan tersebut selaras dengan teori Legitimasi yaitu yang menyatakan bahwa Legitimasi 
organisasi dapat dilihat sebagai sesuatu yang diberikan masyarakat kepada perusahaan dan sesuatu yang diinginkan atau dicari perusahaan dari masyarakat O'Donovan (2002) dalam Hadi (2010).

Penelitian serupa telah banyak dilakukan oleh peneliti sebelumnya dengan berbagai sudut pandang yang berbeda-beda serta menggunakan berbagai metode penelitian kualitatif. Dalam penelitian yang dilakukan oleh Narsa (2016) dengan judul Makna dan Bentuk Corporate Social Responsibility bagi PT PLN (Persero) yang menggunakan metode penelitian fenomenologi dengan paradigma interpretif menghasilkan satu makna CSR yaitu CSR sebagai kewajiban perusahan. Penelitian lain juga dilakukan oleh Oktarizal (2014) dengan judul Makna Corporate Social Responsibility bagi Manajemen Pabrik Gula PT Kebon Agung (Malang, Jawa Timur), pendekatan penelitian yang digunakan adalah pendekatan kualitatif dengan desain riset fenomenologi. Temuan dari penelitian ini adalah bahwa CSR dimaknai sebagai pertanggungjawaban kepada masyarakat, lingkungan, dan negara. Selanjutnya penelitian yang dilakukan oleh Rismawati (2015) dengan judul Memaknai Program Corporate Social Responsibility, suatu Kajian Proses Transformasi Sosial Berbasis Kearifan Lokal, metode penelitian yang digunakan yaitu kualitatif dengan pendekatan studi kasus. Hasil penelitian ini menemukan bahwa no business interruption dimaknai sebagai perintah menjaga lingkungan dan keamanan serta keselamatan kerja karyawan agar aktivitas produksi tidak terhalang.

Penelitian yang dilakukan Rasyid, dkk (2014) dengan metode kualitatif deskriptif menunjukkan hasil bahwa terdapat hubungan yang sangat signifikan antara komunikator, pesan, saluran dengan pemberdayaan masyarakat dan citra perusahaan. selain memiliki dampak positif bagi citra perusahaan, CSR juga memiliki dampak positif bagi masyarakat. Penelitian Narsa dan Irwanto (2014) dalam penelitian menyebutkan bahwa pelaksanaan program CSR telah membawa dampak positif dan nyata bagi masyarakat Kelurahan Karangturi. CSR memperbaiki kondisi masyarakat baik pada bidang kesehatan, pendidikan, ketenagakerjaan, dan penguatan kelembagaan melalui penanganan balita gizi buruk, pemberian beasiswa, maupun kondisi lingkungan berupa ketersediaan air bersih dan keadaan udara. Sebagai tanggapan pemerintah Indonesia atas isu CSR, pemerintah telah membuat beberapa peraturan yang menjadikan landasan pelaksanaan CSR oleh perusahaan dalam negeri. Peraturan tersebut adalah UU No 25 Tahun 2007 tentang Penanam Modal, UU NO 40 tahun 2007 tentang Perseroan Terbatas dan PP No. 47 tahun 2012 tentang Tanggung Jawab Sosial dan Lingkungan Perseroan Terbatas, serta Peraturan Menteri Badan Usaha Milik Negara No. PER-02/MBU/7/2017 tentang Perubahan Kedua atas Peraturan Menteri Badan Usaha Milik Negara No. PER/-09/MBU/07/2015 tentang Program Kemitraan Badan Usaha Milik Negara dengan Usaha Kecil dan Program Bina Lingkungan.

\subsection{Teori Legitimasi}

Beberapa studi tentang tanggung jawab sosial dan lingkungan menggunakan teori legitimasi sebagai basis menjelaskan praktiknya. Dowling \& Pfeffer (1975) dalam Ghozali \& Chariri (2007) menjelaskan bahwa teori legitimasi sangat bermanfaat dalam menganalisis perilaku organisasi karena legitimasi adalah hal yang penting bagi organisasi, batasan-batasan yang ditekankan oleh norma-norma dan nilai-nilai sosial, dan reaksi terhadap batasan tersebut mendorong pentingnya analisis perilaku organisasi dengan memperhatikan lingkungan. Legitimasi masyarakat merupakan faktor strategis bagi perusahaan dalam rangka mengembangkan perusahaan ke depan. Hal itu, dapat dijadikan sebagai wahana untuk 
mengkonstruksi strategi perusahaan, terutama terkait dengan upaya memposisikan diri di tengah lingkungan masyarakat yang semakin maju. Legitimasi organisasi dapat dilihat sebagai sesuatu yang diberikan masyarakat kepada perusahaan dan sesuatu yang diinginkan atau dicari perusahaan dari masyarakat O'Donovan (2002) dalam Hadi (2010).

\subsection{Teori Institusional}

Salah satu masalah yang terdapat pada banyak teori mengenai organisasi adalah bahwa teori-teori tersebut memusatkan bahasanya hanya pada beberapa variabel yang terdapat di dalam organisasi. Ide pokok Institusional adalah bahwa organisasi dibentuk oleh lingkungan institusional yang mengitarinya dan dengan begitu pengamatan atas organisasi harus dilihat sebagai sebuah totalitas simbol, bahasa, ataupun ritual-ritual yang melingkupinya. Oleh sebab itu institusionalisme menolak anggapan bahwa organisasi dan juga konteks institusionalnya yang lebih besar bisa dipahami dengan melakukan agregasi atas pengamatan terhadap perilaku individu Skelley (2002) dalam (Gudono, 2014). Saat ini banyak penelitian Institusionalisme Baru (New Institutionalism) mengkaji pengaruh besar institusi terhadap perilaku manusia melalui aturan-aturan dan norma yang dibangun oleh institusi. Institusi meliputi misalnya angkatan bersenjata, kantor kecamatan, pernikahan, asuransi, kode etik profesi, kelompok gang, pasar, perusahaan, dan masyarakat sebuah kampung Steinmo (2001) dalam Gudono (2014).

\subsection{Definisi Corporate Social Responsibility}

Berdirinya sebuah perusahaan ditengah-tengah kehidupan masyarakat secara langsung akan mengubah tatanan hidup masyarakat serta lingkungan. Perusahaan dengan segala aktivitas operasionalnya tentu memberikan dampak negatif terhadap lingkungan. Tujuan perusahaan untuk memperbaiki keadaan dengan menerapkan program tanggung jawab sosial perusahaan yang biasa disebut Corporate Social Responsibility.

Corporate Social Responsibility(CSR) merupakan suatu bentuk tindakan yang berangkat dari pertimbangan etis perusahaan yang diarahkan untuk meningkatkan ekonomi yang diikuti dengan peningkatan kualitas hidup bagi karyawan berikut keluarganya serta sekaligus peningkatan kualitas hidup masyarakat sekitar dan masyarakat secara lebih luas (Hadi, 2010). European Union Green Paper Corporate Social Responsibility mendefinisikan sebagai konsep dimana perusahaan mengintegrasikan perhatiannya kepada masyarakat dan lingkungan dalam operasi bisnisnya serta dalam interaksinya dengan kepentingan secara sukarela (Azheri, 2011).

Pengertian CSR dapat diperjelas lagi dengan konsep yang dirancang oleh John Elkington yaitu Triple Bottom Line yang dikenal dengan 3P, terdiri dari Profit, People dan Planet. Hakikatnya CSR adalah untuk mencapai pembangunan berkelanjutan dan sustainable business sehingga dunia bisnis saat ini dituntut untuk menyelaraskan pencapaian kinerja ekonomi. Perusahaan selalu berorientasi untuk mencari keuntungan sebanyak-banyaknya untuk terus beroperasi dan berkembang di masa yang akan datang (Profit). Perusahaan tentu harus peduli tentang masyarakat yang berada di sekitar lokasi perusahaan (People). Perusahaan tentunya harus peduli dengan kondisi lingkungan dimana perusahaan berpijak. Kinerja sosial (Planet). CSR adalah konsep etis yang mengutamakan kesejahteraan masyarakat serta lingkungan yang terkena dampak dari aktivitas operasional dari perusahaan. Penerapan CSR dan pengelolaan 
perusahaan yang baik akan menciptakan nilai positif tersendiri bagi perusahaan karena menjalankan bisnisnya dengan berorientasi pada masyarakat., dan kinerja lingkungan (planet) atau disebut Triple Bottom Line performance. Apapun bentuk program CSR yang berlaku, perusahaan harus memiliki prinsip bahwa CSR bukan hanya menggambarkan laba perusahaan akan tetapi digunakan sebagai investasi sosial kepada masyarakat untuk keberlangsungan hidup perusahaan di masa mendatang. Meskipun dalam jangka pendek sangat menguras kas dan menurunkan laba, dalam jangka panjang investasi sosial memberikan banyak manfaat ekonomi bagi perusahaan (Lako, 2010).

\subsection{Regulasi Corporate Social Responsibility di Indonesia}

Beberapa regulasi yang mengatur terkait CSR diantaranya adalah Undang-Undang No. 40 Tahun 2007 tentang Perseroan Terbatas. Bab yang perlu dicermati adalah bab yang mengatur tentang Tanggung Jawab Sosial dan Lingkungan (TJSL) pada Pasal 74. UU No. 40 Tahun 2007 yang berisi (1) Perseroan yang menjelaskan kegiatan usahanya dibidang dan atau berkaitan dengan sumber daya alam wajib melaksanakan Tanggung Jawab Sosial dan Lingkungan. (2) Tanggung Jawab Sosial dan Lingkungan (TJSL) sebagaimana yang dimaksud pada ayat 1 merupakan kewajiban Perseroan yang dianggarkan dan diperhitungkan sebagai biaya perseroan yang pelaksanaannya dilakukan dengan memperhatikan kepatutan dan kewajiban. (3) Perseroan yang tidak melaksanakan kewajiban sebagaimana pada ayat 1 akan dikenai sanksi sesuai ketentuan peraturan perundang-undangan. (4) Ketentuan lebih lanjut mengenai TJSL diatur dengan peraturan pemerintah.

Selain Undang-Undang, terdapat ISO (The International Organization for Standardization) yang mendukung perusahaan harus peduli terhadap lingkungan demi menciptakan lingkungan yang berkelanjutan. Isu mengenai lingkungan juga telah menjadi masalah antar negara. ISO 14001 adalah salah satu seri dari munculnya standar manajemen lingkungan internasional yang bertujuan memasyarakatkan perbaikan yang berkelanjutan dalam Environmental performance perusahaan melalui adopsi dan implementasi environmental management system (EMS). Selanjutnya ada Undang-Undang Nomor 25 Tahun 2007 Pasal 15 tentang penanaman modal. Undang-Undang tersebut menyatakan bahwa setiap penanaman modal di Indonesia wajib melaksanakan Tanggung Jawab Sosial Perusahaan, menghormati tradisi budaya masyarakat sekitar lokasi kegiatan usaha penanam modal dan memenuhi semua ketentuan peraturan perundang-undangan. Peraturan terbaru yang diterapkan khusus di wilayah Jawa Timur yaitu Perda Nomor 4 Tahun 2011 tentang TanggungJawab Sosial Perusahaan pasal 5 ayat 1 menyatakan bahwa Tanggung Jawab Sosial Perusahaan adalah Tanggung Jawab yang melekat pada setiap perusahaan untuk setiap menciptakan hubungan yang serasi, seimbang sesuai dengan lingkungan, nilai, norma dan budaya masyarakat setempat. Pada pasal 6 ayat 1 dijelaskan ruang lingkup TSP meliputi bantuan pembiayaan penyelenggaraan kesejahteraan sosial, kompensasi pemulihan dana atau peningkatan fungsi lingkungan hidup dan memacu pertumbuhan ekonomi berkualitas berbasis kerakyatan yang selaras dengan program-program pemerintah daerah (Maharani, 2016:56). Perusahaan yang berdiri khususnya di Indonesia, beberapa diantaranya merupakan Badan Usaha Milik Negara (BUMN). Program CSR bagi BUMN adalah Program Kemitraan dan Bina Lingkungan (PKBL). Pelaksanaan CSR oleh BUMN diatur dalam PER-05/MBU/2007 yang saat ini diperbarui lagi dalam PER- 09/MBU/07/2015. 


\section{Metode}

Penelitian ini termasuk jenis penelitian kualitatif dengan fenomenologi, Pemilihan metode dalam penelitian ini didasarkan pada paradigma atau cara pandang peneliti terhadap realita. Penelitian ini menggunakan paradigma interpretif yang lebih menekankan pada makna atau interpretasi seseorang (to understand) terhadap objek, sehingga paradigma ini tidak untuk menjelaskan (to explain) dan meramalkan (to predict), hanya memaknai. Peneliti mendapatkan sumber data dengan data primer melalui wawancara langsung ke perusahaan dan data sekunder melalui dokumen perusahaan dan peraturan-peraturan regulasi pengelolaan CSR. Penelitian ini merujuk fenomenologi transendental milik Husserl (18591938) yang terdiri dari empat tahap analisis data yaitu, epoche, reduksi fenomenologi, variasi imajinasi, serta sintesis makna dan esensi. Pelaksanaan penelitian ini menggunakan pendekatan fenomenologi, diupayakan pula terjadi proses reduksi, interpretasi, dan analisis data dengan mengikuti alur pendekatan tersebut. Proses reduksi dilakukan untuk mencari inti atau pokok persoalan dari data yang diperoleh. Untuk menginterpretasi data dilakukan kembali hasil reduksi sebagai bahan untuk menganalisis atau menyimpulkan hasil-hasil temuan. Peneliti sudah mendapatkan data maka melanjutkan ke tahap analisis dan penafsiran data. Berdasarkan data yang diperoleh, peneliti melakukan analisis data dengan melalui tahap reduksi melalui bracketing dengan cara memberi tanda kurung untuk mendapatkan data tekstural, kemudian horizonalizing yaitu membandingkan persepsi setiap informan terkait objek, kemudian horizon yaitu mengelompokkan temuan dari horizonalizing dan memasukkan ke dalam tema terkait dengan objek tahap ini sebagai pemaknaan yang lebih mendalam.

\section{Hasil dan Pembahasan}

\subsection{Manfaat CSR yang Dirasakan Masyarakat}

Dengan berdirinya perusahaan yang berada tidak jauh dari pemukiman warga, perusahaan tentunya membawa dampak yang baik bagi masyarakat sekitarnya, terutama meningkatnya perekonomian masyarakat. Pengaruh tersebut dapat dilihat melalui hasil wawancara Bapak Slamet menyatakan:

" Alhamdulillah mas banyak sekali manfaatnya, perekonomian disini lebih baik pokoknya, untuk dampak dari SUB ini, yang pertama warga disini banyak yang bekerja disitu sekitar kurang lebih 200-300 orang, terus semisal ada pekerjaan borongan dari perusahaan itu dikasihkan dan ditawarkan ke masyarakat sekitar terlebih dahulu, misal butuh pegawai untuk mengangkut kayu gelondongan itu mas. Kemudian juga untuk daur ulang triplek-triplek tipis itu mas, itu dikasihkan ke warga dengan gratis dan kemudian dibeli lagi oleh masyarakat, alhamdulillah banget mas untuk masyarakat sekitar sini"

Berdasarkan wawancara dengan Bapak Slamet, dapat diketahui bahwa dampak pendirian pabrik yang cukup dirasakan adalah besarnya jumlah penyerapan tenaga kerja dari warga sekitar, termasuk adanya kerja sama antara perusahaan dengan warga seperti pekerja borongan untuk mengangkut kayu gelondongan, kemudian adanya daur ulang triplek vinir yang kurang layak kemudian disambung dan ditambal setelah itu dibeli lagi oleh pihak perusahaan. Pernyataan yang sama dengan hasil wawancara Bapak Saifur menyatakan:

"Oh, untuk vinir triplek itu adalah pemberdayaan masyarakat khususnya ibu-ibu rumah tangga, ja di perusahaan memberikan potongan-potongan triplek untuk disambung ulang. Dan bahan tersebut diberikan gratis oleh SUB, kemudian kalau sudah jadi nanti dibeli lagi oleh SUB. Kalau gak salah Rp400- Rp600/lembar". 
Pernyataan Bapak Saifur juga yang menyatakan adanya pemberdayaan masyarakat khususnya ibu-ibu rumah tangga melalui daur ulang triplek vinir oleh perusahaan, kemudian dari pemberdayaan tersebut, warga sekitar mendapatkan manfaat besar yang diterima dari pemberdayaan tersebut. Hal serupa dinyatakan oleh Ibu Sriatin yang menyatakan:

"Alhamdulillah mas, dengan adanya pekerjaan triplek ini sedikit banyaknya bisa membantu kehidupan saya. Disyukuri mawon rejeki sampun enten seng ngatur. Alhamdulillah “

Pernyataan dari Ibu Sriatin sebagai pelaku pemberdayaan masyarakat oleh pihak perusahaan SUB bahwa masyarakat sekitar merasakan dampak yang positif akan hadirnya perusahaan ini. Melalui program-program CSR salah satunya pemberdayaan masyarakat dalam mendaur ulang triplek menjadi bahan dasar yang masih bernilai bagi perusahaan. Masyarakat sangat terbantu dengan hadirnya perusahaan ditengah-tengah kehidupan masyarakat, manfaat lain yang secara tidak langsung mempengaruhi kesejahteraan masyarakat sekitar perusahaan adalah tumbuhnya perekonomian di sekitar perusahaan, hal serupa juga juga diungkapkan oleh Bapak Slamet menyatakan:

"Jelas, itu menambah lapangan pekerjaan karena dengan adanya perusahaan, dengan berkumpulnya banyak orang, ekonomi menjadi bergerak terutama ekonomi rumah kost, warung, restoran, catering, dan laundry menjadi bergerak, perekonomiannya itu jalan atau bisa bergerak, Alhamdulillah seperti itu mas"

Berdasarkan wawancara tersebut bahwa dengan adanya perusahaan ini tentunya akan menggerakkan perekonomian masyarakat sekitar khususnya dalam usaha rumah kos, warung, catering, dan laundry. Masyarakat merasakan manfaat dari hadirnya perusahaan ini. Banyak warung-warung sekitar perusahaan dan banyak juga masyarakat yang membangun kos-kosan dan usaha-usaha lainnya. Secara tidak langsung perekonomian masyarakat sekitar menjadi meningkat dan terbantu oleh hadirnya PT.SUB ini.

\subsection{Makna CSR pada PT SUB Jombang}

Fenomena pada penelitian ini bahwa segala aktivitas yang dilaksanakan berawal dari nilai kewajiban. Nilai-nilai kewajiban tersebut mempengaruhi seluruh aktivitas termasuk pelaksanaan program CSR di dalam penelitian ini. Kewajiban merupakan salah satu yang harus dilakukan dengan penuh tanggung jawab. Berdasarkan kewajiban dan kesadaran informan, peneliti telah menemukan makna CSR pada perusahaan PT.SUB terbagi menjadi tiga bentuk makna yaitu CSR sebagai kepatuhan terhadap peraturan pemerintah, CSR sebagai Kesadaran Perusahaan terhadap Masyarakat dan CSR sebagai shodaqoh.

\subsubsection{Kepatuhan Terhadap Peraturan Pemerintah}

Penggalian makna CSR ini dibuka oleh informan yang merupakan Manajer CSR dari PT SUB Jombang, yaitu Ibu Dyah. Ketika beliau ditanya mengenai apa dan kenapa harus ada CSR, beliau mengatakan:

"CSR ini sudah diatur juga oleh pemerintah melalui undang-undang mas. Otomatis harus mematuhinya. Ya... Meskipun perusahaan ini swasta yang tujuan utamanya berfokus juga untuk meningkatkan produktivitas, perusahaan juga memiliki tanggung jawab pada masyarakat melalui program CSR. Ya kurang lebih seperti itu mas". (bracketing) 
Berdasarkan pendapat awalnya, Ibu Dyah menyadari bahwa CSR dilakukan sebagai bentuk kepatuhan terhadap peraturan pemerintah melalui Undang-Undang (noema). Semua peraturan termasuk CSR mengacu pada Undang-Undang No 40 Tahun 2007 tentang Perseroan Terbatas menekankan bahwa setiap korporasi yang menggunakan sumber daya alam sebagai bahan baku utama wajib melaksanakan Tanggung Jawab Sosial (CSR). Selain itu, sesuai dengan pasal 74 UU Nomor 40 Tahun 2007 tentang Perseroan Terbatas, kewajiban soal pemberian CSR tersebut hanya terbatas pada perseroan atau perusahaan yang kegiatan usahanya berkaitan dengan sumber daya alam (eidetic reduction).

Pemahaman Ibu Dyah yang menganggap CSR sebagai suatu kewajiban karena kewajiban mematuhi peraturan yang telah ditetapkan dan harus dipatuhi oleh perusahaan (noesis). Hal serupa juga diungkapkan Bapak Deddy selaku Manager Accounting PT SUB juga mengatakan:

"CSR menurut pribadi saya ya, kewajiban yang harus dilaksanakan mas demi mensejahterakan masyarakat, kan juga sudah diatur oleh pemerintah melalui Undang-Undang" (bracketing)

Bapak Deddy yang menganggap CSR sebagai kewajiban (noema) sebagaimana apa yang telah disampaikan oleh Ibu Dyah (horizon analyzing). Bapak Deddy juga berpendapat demikian karena kesadaran terhadap sifat peraturan yang memang wajib dipatuhi (noesis). Selain Ibu Dyah dan Pak Deddy, salah satu staff CSR yaitu Ibu Linda juga memandang CSR merupakan suatu kewajiban bagi perusahaan (horizinanalizing).

"Iya wajib, semua diatur oleh regulasi pemerintah, mulai dari CSR dan PKBL itu diatur oleh Permen guna untuk mengatur CSR dan PKBL itu agar tidak keluar dari koridornya" (bracketing)

Pernyataan dari ketiga informan ini muncul karena beliau sadar bahwa perusahaan berdiri di bawah naungan negara sehingga segala peraturan yang ditetapkan oleh pemerintah wajib dipatuhi dan dijalankan (eidetic reduction).

\subsubsection{CSR sebagai Kesadaran Perusahaan terhadap Masyarakat}

Perusahaan selalu erat dikaitkan dengan etika bisnis. Dengan adanya etika bisnis maka pelaksanaan bisnis akan lebih mengarah ke bisnis yang lebih baik. Etika bisnis akan membuat manajemen perusahaan berpikir bahwa usaha yang dilakukan dengan baik dan sesuai kode etik yang mengarahkan pada kebaikan dalam usaha. Ketika etika menjadi patokan manajemen perusahaan, maka tanggung jawab moral menjadi sifat manajemen perusahaan tersebut. Di dalam tanggung jawab moral, perusahaan tidak hanya mementingkan kepentingan pribadi, tetapi mementingkan lingkungan sekitar dan masyarakatnya. CSR merupakan salah satu bentuk dari tanggung jawab moral perusahaan. Pembahasan dalam poin ini ditujukan untuk mengungkap makna yang tersembunyi dari kesadaran yang menjadi dasar dalam menjalankan tugas sosial perusahaan.

Kesadaran memang datang dari persepsi dan pemikiran yang secara didasari oleh individu yang menganggap bahwa CSR adalah suatu kewajiban perusahaan. Kewajiban dalam melaksanakan CSR telah memberikan suatu sistem mental sehingga menumbuhkan suatu kesadaran diri dalam manajemen PT SUB untuk melakukan CSR. Ibu Dyah menyadari bahwa perusahaan tidak hanya bertugas untuk menghasilkan profit saja, tetapi perusahaan memiliki 
tugas sosial untuk memajukan masyarakat sekitar (noesis). Seperti yang disampaikan oleh beliau sebagai berikut:

\begin{abstract}
"gini mas, kalau prinsip yang ditekankan perusahaan itu seperti ini, kalau perusahaan menginginkan peningkatan laba, otomatis masyarakat sekitar juga harus semakin maju atau ikut merasakannya. jadi ini sudah tugas perusahaan mas, kayak ada dorongan sosial seperti itu atau kesadaran". (bracketing)
\end{abstract}

Berdasarkan hasil wawancara tersebut bahwa perusahaan tidak hanya bertugas untuk menghasilkan profit saja (noesis) melainkan juga untuk memajukan masyarakat sekitar perusahaan (noema). Untuk menjaga kelangsungan hidup perusahaan, maka perusahaan harus peka terhadap perubahan lingkungan sekitar perusahaan. Sinkronisasi antara kepentingan perusahaan dan kepentingan masyarakat perlu dilakukan untuk menghindari halhal yang tidak diinginkan oleh perusahaan dan demi terciptanya suatu hubungan yang harmonis antara perusahaan dengan masyarakat. Oleh sebab itu CSR tidak cukup hanya dianggap menjadi kewajiban perusahaan tetapi CSR harus menjadi kesadaran perusahaan (eidetic reduction). Seperti yang diungkapkan Bapak Deddy Beliau mengatakan:

\begin{abstract}
"Untuk menjaga kelangsungan hidup perusahaan, maka perusahaan harus peka terhadap perubahan lingkungan sekitar perusahaan. Sinkronisasi antara kepentingan perusahaan dan kepentingan masyarakat perlu dilakukan untuk menghindari hal-hal yang tidak diinginkan oleh perusahaan dan demi terciptanya suatu hubungan yang harmonis antara perusahaan dengan masyarakat. Oleh sebab itu CSR tidak cukup hanya dianggap menjadi kewajiban perusahaan tetapi CSR harus menjadi kesadaran perusahaan. Adanya kesadaran juga bahwa perusahaan hadir ditengah-tengah masyarakat sehingga dampak yang dihasilkan operasional perusahaan akan dialami oleh masyarakat secara langsung maupun tidak langsung. Ketika para stakeholder sudah merasa dipenuhi apa yang diinginkan, maka kegiatan operasional perusahaan akan berjalan sesuai apa yang diharapkan perusahaan dan tidak ada kontra dari pihak stakeholder". (bracketing)
\end{abstract}

Pernyataan yang dipaparkan oleh Ibu Dyah dan Bapak Deddy bahwa perusahaan tidak hanya bertujuan untuk meningkatkan laba saja, melainkan adanya keseimbangan antara perusahaan dan masyarakat. Ketika perusahaan menginginkan laba yang tinggi otomatis masyarakat juga harus meningkat kesejahteraannya. Manajemen perusahaan tentu berharap agar perusahaan bisa tumbuh dan berkembang untuk kedepannya serta dapat terus beroperasi dalam jangka waktu yang lama untuk memenuhi komitmen, kewajiban, tujuan dan sebagainya. Hal tersebut tidak akan terlaksana tanpa dukungan dari masyarakat, khususnya masyarakat sekitar perusahaan (eidetic reduction).

\title{
3.2.3. CSR sebagai Shodaqoh
}

Tanggung Jawab sosial perusahaan merupakan sebuah konsep yang berhubungan, namun pandangan perusahaan terhadap CSR memiliki makna yang berbeda, pada wawancara kepada karyawan bagian staff CSR di PT.SUB telah memaknai bahwa melakukan CSR itu termasuk Amalan Shodaqoh (noema) terhadap masyarakat sekitar perusahaan yang kurang mampu atau yang membutuhkan (noesis). Berikut adalah hasil wawancara dengan Ibu Linda sebagai staff CSR PT.SUB:

"Perusahaan ini kan yang awalnya menjadi pro dan kontra perusahaan harus mengeluarkan dana untuk CSR agar perusahaan merasa nyaman saat melakukan kegiatan operasional, ya alhamdulillah dengan adanya CSR saya merasa itu saya 
anggap seperti amal atau shodaqoh, jadi ya kita harus ikhlas demi perkembangan perusahaan dan kemajuan masyarakat sekitar karena adanya CSR ini" (bracketing)

Dari hasil wawancara diatas bahwa Ibu Linda menganggap bahwa CSR adalah suatu kesadaran untuk berbuat amal atau shodaqoh dimana beliau sendiri juga seorang muslim yang ingin memberikan sebagian dana CSR sesuai dengan prosedur yang ditetapkan perusahaan sendiri dan bentuk kepatuhan terhadap Tuhan yang mewajibkan seorang muslim membantu seseorang yang lebih membutuhkan (eidetic reduction).

Pembahasan dalam penelitian ini merupakan hasil analisis melalui intuisi penelitian sebagai instrumen utama dengan kajian teori institusional Corporate Social Responsibility (CSR) yang ada pada PT SUB dan Undang-Undang terkait Corporate Social Responsibility (CSR). Pembahasan akan dibagi berdasarkan dua dasar teori yang berkaitan dengan makna yang telah didasari oleh informan untuk menjawab fokus penelitian yaitu bagaimana makna CSR dalam perspektif manajemen PT SUB dan akan dijelaskan sebagai berikut.

\subsection{Kepatuhan Terhadap Pemerintah Berdasarkan Teori Institusi.}

Definisi secara umum mengenai Tanggung Jawab Sosial Perusahaan atau yang lebih dikenal dengan Corporate Social Responsibility (CSR) merupakan tindakan yang berawal dari pertimbangan etis perusahaan yang diarahkan untuk meningkatkan ekonomi yang dibarengi dengan peningkatan kualitas hidup bagi karyawan berikut keluarganya serta sekaligus peningkatan kualitas hidup masyarakat sekitar dan masyarakat lebih luas (Hadi, 2014: 48). Tetapi dalam kenyataannya, tidak semua perusahaan dapat menyeimbangkan antara peningkatan ekonomi dan kesejahteraan masyarakat di sekitarnya melalui program CSR yang telah dicanangkan. Perusahaan cenderung mengarah kepada peningkatan ekonomi sebagaimana tujuan didirikannya perusahaan yaitu memperoleh laba sebesar-besarnya tanpa memperhatikan dampak dari kegiatan usaha yang dilakukan oleh perusahaan.

Berpijak dari realitas dampak tersebut maka pemerintah bersikeras untuk membuat CSR yang pada awalnya merupakan tindakan etis dari sebuah perusahaan diubah menjadi norma yang wajib dilaksanakan oleh perusahaan. hal tersebut ditindaklanjuti oleh peraturan pemerintah mengenai bentuk pelaksanaan CSR yaitu peraturan Undang-Undang No. 40 Tahun 2007 tentang Perseroan Terbatas. Bab yang perlu dicermati adalah bab yang mengatur tentang Tanggung Jawab Sosial dan Lingkungan (TJSL) pada Pasal 74. UU No. 40 Tahun 2007 yang berisi perseroan yang menjelaskan kegiatan usahanya dibidang dan atau berkaitan dengan sumber daya alam wajib melaksanakan Tanggung Jawab Sosial dan Lingkungan.

Tanggung Jawab Sosial dan Lingkungan (TJSL) sebagaimana yang dimaksud pada ayat (1) merupakan kewajiban Perseroan yang dianggarkan dan diperhitungkan sebagai biaya perseroan yang pelaksanaannya dilakukan dengan memperhatikan kepatutan dan kewajiban.

Perseroan yang tidak melaksanakan kewajiban sebagaimana pada ayat (1) akan dikenai sanksi sesuai ketentuan peraturan perundang-undangan. Ketentuan lebih lanjut mengenai TJSL diatur dengan peraturan pemerintah.

Sesuai teori Institusi oleh DiMaggio \& Powell (1983) dalam Gudono (2014) menjelaskan bahwa organisasi dibentuk oleh kekuatan-kekuatan diluar dirinya melalui proses ketaatan. Ketaatan atau kepatuhan PT SUB merupakan proses pembentukan kekuatan atau aturan di dalam perusahaan tersebut sehingga peraturan Undang-Undang yang mewajibkan 
pelaksanaan CSR akan mendorong manajemen PT SUB untuk menerapkan setiap bagian bagian peraturan yang wajib termasuk menerapkan CSR dalam bentuk PKBL.

Peraturan yang mewajibkan pelaksanaan CSR tersebut telah mempengaruhi pemahaman serta pemaknaan CSR bagi manajemen PT SUB. Norma yang mewajibkan perusahaan untuk melaksanakan CSR telah membuat pergeseran pola pikir perusahaan dalam memahami CSR. Sifat CSR yang pada awalnya dianggap perusahaan sebagai voluntary dengan adanya peraturan tersebut anggapan perusahaan mengenai CSR berubah menjadi mandatory. Hal tersebut turut berimbas pada manajemen PT SUB yang beranggapan bahwa CSR adalah suatu kewajiban yang didasarkan atas suatu peraturan sesuai dengan institusional teori yang memandang aturan (rules) menjadi dasar bagi semua perilaku (Steinmo, 2001) dalam Asshiddiqie (2015). Manajemen PT SUB menyadari bahwa PT SUB berdiri dibawah naungan peraturan pemerintah harus mematuhi peraturan yang berlaku. Zucker (1987) berpendapat organisasi sering dipengaruhi oleh sumber eksternal dalam lingkungan seperti negara yang menekan organisasi untuk memiliki ketaatan (persepsi normatif). Pemaknaan CSR oleh PT SUB dipengaruhi oleh lembaga yang lebih tinggi yaitu kementerian pemerintah merupakan tekanan yang harus dipatuhi oleh manajemen PT SUB. Persepsi normatif yang telah disebutkan di atas membuat manajemen PT SUB memaknai CSR sebagai suatu kewajiban atau kepatuhan mematuhi peraturan pemerintah.

Peraturan memang telah mengekang PT SUB dalam pelaksanaan CSR. Hal tersebut diungkapkan oleh salah satu informan sebagai berikut:

"CSR ini sudah diatur juga oleh pemerintah melalui undang-undang mas. Otomatis harus mematuhinya. Ya... Meskipun perusahaan ini swasta yang tujuan utamanya berfokus juga untuk meningkatkan produktivitas, perusahaan juga memiliki tanggung jawab pada masyarakat melalui program CSR. Ya kurang lebih seperti itu mas".

Tetapi dalam pelaksanaannya, mematuhi peraturan pemerintah hal yang dapat merugikan pihak PT SUB. Perusahaan mematuhi peraturan berarti telah memperertimbangkan untung dan ruginya, jika manajemen PT SUB memilih untuk mematuhi peraturan, maka dapat disimpulkan bahwa mematuhi peraturan lebih menguntungkan daripada tidak mematuhinya.

Dalam upaya untuk mewujudkan peraturan pemerintah, PT SUB telah mengadakan berbagai program yang bertujuan untuk meningkatkan taraf hidup masyarakat. Programprogram tersebut dilaksanakan melalui bentuk pengabdian kepada masyarakat oleh manajemen PT SUB. Program-program CSR perusahaan yaitu (1) Penyerapan tenaga kerja lokal di wilayah sekitar perusahaan adalah 200-300 orang, sedangkan untuk total penyerapan di wilayah Jombang sebanyak 2.701 orang. (2) Perbaikan sarana prasarana penunjang transportasi serta fasilitas fisik, dengan jumlah total bantuan dana tahun 2009-2014 sebesar Rp 4.098.630.109. (3) Bantuan dana untuk peringatan hari besar nasional maupun keagamaan. Dengan alokasi dana dari tahun 2007-2016 mencapai Rp 823.341.500. (4) Bantuan bibit pohon dan alat pertanian, dengan bantuan total dana dari tahun 2007-2016 sebesar RP 4.130.589.134. (5) Bantuan beasiswa dan orang tua asuh dari tahun 2007-2016 sebesar Rp 708.000.000. (6) Pemanfaatan limbah padat bukan B3. Pembuangan limbah padat yang dilakukan perusahaan sebenarnya dapat mengganggu lingkungan utamanya saluran air yang berada tidak jauh dari lokasi pembuangan, namun limbah padat terutama kulit kayu banyak 
dimanfaatkan oleh beberapa produsen tahu dan kerupuk sebagai bahan bakar. Dengan adanya limbah ini para produsen dapat menekan biaya produksi mereka. Karena limbah ini diberikan secara gratis. (7) Adanya kerja sama antar perusahaan dengan masyarakat sekitar perusahaan. program ini bisa dibilang merupakan pemberdayaan yang melibatkan dan menyerap banyak tenaga kerja, utamanya ibu rumah tangga yang menganggur atau memiliki banyak waktu luang. Pemberdayaan oleh PT SUB untuk mengolah atau mengelem triplek yang sobek/rusak, dan itu karena per lembar kayu lapis yang telah siap diproses ke tahap selanjutnya oleh pabrik dihargai oleh PT SUB sebesar Rp 200-300/lembar, sedangkan masyarakat bisa menghasilkan minimal 100-150/lembar. Jadi, pendapatan minimal masyarakat yang tergabung dalam program ini paling sedikit antara Rp. 600.000 hingga Rp. 1.350 .000 tiap bulan.

Karakteristik setiap individu menjadi sangat penting dalam penelitian ini, karena rasa pada seseorang terhadap tumpah darahnya mendorong individu untuk bekerja dengan serius dan sangat hati hati. Oleh sebab, itu ketika individu yang bekerja disuatu perusahaan adalah penduduk pribumi maka implementasi pekerjaan akan dilakukan dengan sangat serius, salah satunya dalam menjaga kelestarian lingkungan baik sumber daya hayati maupun non hayati.

Berdasarkan pada karakteristik gender responden perempuan dan laki-laki mempunyai sudut pandang yang berbeda, tetapi mengenai hasil penelitian ini yang ingin mengetahui makna CSR pada perusahaan PT.SUB, mendapatkan suatu makna CSR yaitu CSR sebagai bentuk kepatuhan terhadap peraturan pemerintah pemerintah. Oleh karena itu, dari hasil tersebut ternyata karakteristik gender perempuan dan laki-laki mempunyai pemikiran yang sama karena perusahaan harus wajib dan mematuhi peraturan pemerintah demi berjalannya suatu kegiatan operasional perusahaan yang berdampak langsung terhadap lingkungan dan masyarakat sekitar. Berdasarkan penelitian ini, peneliti menemukan pendapat bahwa gender laki-laki dan perempuan mengungkapkan tentang peraturan pemerintah adalah sesuatu yang wajib dipatuhi dan dijalankan. Hal tersebut terpampang dalam Undang-Undang No. 40 Tahun 2007 tentang Perseroan Terbatas, pada pasal 74 No. 40 Tahun 2007.

Penelitian yang dilakukan Handajani, Subroto et al.,(2014) dalam Hadya \& Susanto (2018) menyatakan bahwa variasi gender berpengaruh terhadap peningkatan pengungkapan Corporate social responsibility, dalam hasil penelitian tersebut terlihat baik laki-laki atau perempuan yang menduduki posisi sebagai dewan direksi sama-sama berorientasi untuk melakukan pengembangan Corporate Social Responsibility. Keadaan tersebut menunjukan bahwa setiap individu yang dibedakan atas gender sama-sama telah memiliki kesadaran yang tinggi untuk benar-benar melaksanakan pengungkapan Corporate Social Responsibility.

Pada saat ini gender bukanlah menjadi pembeda yang mempengaruhi pengungkapan Corporate Social Responsibility. Baik laki-laki atau wanita pada saat ini telah sama-sama memiliki kesadaran yang kuat untuk melakukan pengungkapan Corporate Social Responsibility. Keadaan tersebut menunjukan bahwa setiap individu yang dibedakan atas gender sama-sama telah memiliki kesadaran yang tinggi untuk benar-benar melaksanakan pengungkapan Corporate Social Responsibility pada perusahaan Hadya \& Susanto (2018). Corporate Social Responsibility Berdasarkan Teori Legitimasi.

Masalah legitimasi dapat muncul ketika perusahaan beroperasi dengan tidak memperhatikan nilai-nilai dan norma-norma sosial yang berlaku pada masyarakat. Masyarakat adat sangat memegang teguh pada norma dan nilai yang diwariskan oleh nenek moyang sehingga apabila dengan adanya aktivitas perusahaan tersebut nilai dan norma yang 
selama ini dijaga menjadi rusak tentulah hal ini bertentangan dengan apa yang diyakini oleh masyarakat tersebut. Dengan demikian pengungkapan tanggung jawab sosial perusahaan diperlukan sebagai salah satu media bagi perusahaan untuk mengkomunikasikan dampak yang disebabkan oleh adanya aktivitas perusahaan kepada pihak yang berkepentingan dan masyarakat harus dengan tujuan untuk memenuhi komitmen perusahaan terhadap kelompok dan individual dalam lingkungan perusahaan (Lindawati \& Puspita, 2015).

Dalam pengungkapan CSR, salah satunya tujuan dari manajemen PT SUB adalah membentuk suatu legitimasi antara perusahaan dan masyarakat. Hal tersebut terlihat dari dua makna CSR yang telah didasari oleh manajemen PT SUB sebagai berikut :

\subsection{CSR sebagai Kesadaran Perusahaan terhadap Masyarakat}

Secara alamiah manusia adalah sosial yang tidak bisa hidup sendiri sehingga setiap manusia selalu hidup bermasyarakat. Karena hanya dengan hidup bermasyarakat manusia dapat mempertahankan kehidupannya. Begitu Pula dengan suatu entitas bisnis yang berdiri di tengah-tengah masyarakat. Perusahaan sebagai entitas bisnis tidak bisa menjalankan kegiatan bisnisnya dengan baik tanpa dukungan dari masyarakat sekitar perusahaan. oleh sebab itu perusahaan harus memberikan komitmen mereka terhadap masyarakat sekitar untuk menjamin keberlanjutan perusahaan.

PT SUB sebagai entitas bisnis yang berdiri di tengah-tengah masyarakat maka perusahaan membutuhkan legitimasi sosial, yakni penerimaan dan dukungan sosial dari masyarakat setempat. Keberadaan PT SUB di tengah lingkungan masyarakat telah memberikan pengaruh baik secara langsung maupun tidak langsung terhadap lingkungan eksternal yaitu masyarakat. Eksistensi PT SUB berpotensi besar mengubah lingkungan masyarakat, baik ke arah negatif maupun positif. Untuk mencegah timbulnya legitimacy gap yang dapat memicu konflik dengan masyarakat, PT SUB telah melaksanakan pengungkapan tanggung jawab sosial yang dimaksudkan untuk memperhatikan masyarakat yang telah menerima dan memberikan dukungan kepada perusahaan yang berdiri di tengah-tengah mereka. Hal tersebut diungkapkan pada saat wawancara berlangsung sebagai berikut:

\footnotetext{
"Untuk menjaga kelangsungan hidup perusahaan, maka perusahaan harus peka terhadap perubahan lingkungan sekitar perusahaan. Sinkronisasi antara kepentingan perusahaan dan kepentingan masyarakat perlu dilakukan untuk menghindari hal-hal yang tidak diinginkan oleh perusahaan dan demi terciptanya suatu hubungan yang harmonis antara perusahaan dengan masyarakat. Oleh sebab itu CSR tidak cukup hanya dianggap menjadi kewajiban perusahaan tetapi CSR harus menjadi kesadaran perusahaan. Adanya kesadaran juga bahwa perusahaan hadir ditengah-tengah masyarakat sehingga dampak yang dihasilkan operasional perusahaan akan dialami oleh masyarakat secara langsung maupun tidak langsung. Ketika para stakeholder sudah merasa dipenuhi apa yang diinginkan, maka kegiatan operasional perusahaan akan berjalan sesuai apa yang diharapkan perusahaan dan tidak ada kontra dari pihak stakeholder"
}

Tobin et al., (2002) dalam Hadi (2014) menyatakan bahwa legitimasi dapat diperoleh jika terdapat kesesuaian antara keberadaan perusahaan telah sesuai dengan eksistensi sistem nilai yang ada dalam masyarakat dan lingkungan. Dengan diterimanya PT SUB dalam lingkungan masyarakat, maka dapat disimpulkan bahwa telah ada kesesuaian antara operasi perusahaan dengan pengharapan masyarakat, termasuk kesesuaian pada nilai sosial dan norma, dengan kata lain proses legitimasi yang dilakukan oleh perusahaan telah berhasil. 
Legitimasi masyarakat merupakan faktor strategis bagi perusahaan dalam rangka mengembangkan perusahaan ke depan. Hal itu, dapat dijadikan sebagai wahana untuk mengkonstruksi strategi perusahaan, terutama terkait dengan upaya memposisikan diri di tengah lingkungan masyarakat yang semakin maju. Legitimasi organisasi dapat dilihat sebagai sesuatu yang diberikan masyarakat kepada perusahaan dan sesuatu yang diinginkan atau dicari perusahaan dari masyarakat O'Donovan (2002) dalam Hadi, (2010). Hal tersebut terlihat jelas bahwa perusahaan memberikan tanggung jawab sosial (CSR) sebagai strategis perusahaan demi mendapatkan apa yang diinginkan perusahaan yaitu persepsi positif dari masyarakat, dengan memberikan program-program CSR melalui pemberdayaan masyarakat. Untuk menjaga kelangsungan hidup perusahaan, maka perusahaan harus peka terhadap perubahan lingkungan sekitar perusahaan. Sinkronisasi antara kepentingan perusahaan dan kepentingan masyarakat perlu dilakukan untuk menghindari hal-hal yang tidak diinginkan oleh perusahaan dan demi terciptanya suatu hubungan yang harmonis antara perusahaan dengan masyarakat. Oleh sebab itu CSR tidak cukup hanya dianggap menjadi kewajiban perusahaan tetapi CSR harus menjadi kesadaran perusahaan. Dengan adanya program CSR masyarakat merasakan dampak yang positif dan masyarakat merasa terbantu dengan adanya program CSR yaitu salah satunya pemberdayaan masyarakat. Berikut salah satu ungkapan oleh pihak eksternal yang merasakan dampak program CSR perusahaan:

"Alhamdulillah mas banyak sekali manfaatnya, perekonomian disini lebih baik pokoknya, untuk dampak dari SUB ini, yang pertama warga disini banyak yang bekerja disitu sekitar kurang lebih 200-300 orang, terus semisal ada pekerjaan borongan dari perusahaan itu dikasihkan dan ditawarkan ke masyarakat sekitar terlebih dahulu, misal butuh pegawai untuk mengangkut kayu gelondongan itu mas. Kemudian juga untuk daur ulang triplek-triplek tipis itu mas, itu dikasihkan ke warga dengan gratis dan kemudian dibeli lagi oleh masyarakat, alhamdulillah banget mas untuk masyarakat sekitar sini"

Pernyataan serupa juga dinyatakan oleh pihak eksternal yang terkait pemberdayaan masyarakat melalui daur ulang triplek vinir, yang merasa terbantu adanya program tersebut, beliau menyatakan:

"Alhamdulillah mas, dengan adanya pekerjaan triplek ini sedikit banyaknya bisa membantu kehidupan saya. Disyukuri mawon rejeki sampun enten seng ngatur. Alhamdulillah"

Dari pernyataan pihak eksternal yang merasakan dampak positif dari kegiatan CSR perusahaan merasa terbantu dan merasakan kemajuan perekonomian di sekitar perusahaan. Dengan pernyataan tersebut dapat disimpulkan bahwa adanya sinkronisasi antara pihak eksternal dan internal perusahaan. Perusahaan mendapatkan citra positif oleh masyarakat dan masyarakat merasakan cukup terbantu oleh program CSR salah satunya yaitu pemberdayaan masyarakat.

Legitimasi organisasi dapat dilihat sebagai sesuatu yang diberikan masyarakat kepada perusahaan dan sesuatu yang diinginkan atau dicari perusahaan dari masyarakat O’Donovan (2002) dalam Hadi, (2010). Dalam pengertian teori Legitimasi tersebut perusahaan menginginkan sesuatu dari masyarakat, hal tersebut adalah persepsi positif dari masyarakat atau citra baik masyarakat atas perusahaan. Ketika apa yang diinginkan masyarakat sudah terpenuhi otomatis masyarakat sudah merasa puas dan merasa diperhatikan oleh perusahaan dengan program CSR melalui pemberdayaan masyarakat. Kepuasan masyarakat atas perhatian 
perusahaan dalam pemberdayaan masyarakat dinyatakan oleh salah satu informan yang merasakan manfaat dari program CSR perusahaan yaitu menyatakan:

"Alhamdulillah mas banyak sekali manfaatnya, perekonomian disini lebih baik pokoknya, untuk dampak dari SUB ini, yang pertama warga disini banyak yang bekerja disitu sekitar kurang lebih 200-300 orang, terus semisal ada pekerjaan borongan dari perusahaan itu dikasihkan dan ditawarkan ke masyarakat sekitar terlebih dahulu, misal butuh pegawai untuk mengangkut kayu gelondongan itu mas. Kemudian juga untuk daur ulang triplek- triplek tipis itu mas, itu dikasihkan ke warga dengan gratis dan kemudian dibeli lagi oleh masyarakat, alhamdulillah banget mas untuk masyarakat sekitar sini"

Berdasarkan hasil yang ditemukan pada informan perempuan bahwa karakteristik gender perempuan lebih memberikan pendapat yang lebih detail dan lebih terbuka. Selain itu gender perempuan pada penelitian ini yang memberikan pendapat terkait makna CSR bahwa kepatuhan terhadap peraturan pemerintah merupakan suatu kewajiban, tidak hanya itu saja pada gender perempuan dalam penelitian ini juga memberikan pendapat lain yaitu kesadaran perusahaan terhadap masyarakat dan lingkungan. Karena perempuan pada umumnya lebih memiliki pemikiran yang mendetail terkait dalam analisis pengambilan keputusan. Mereka cenderung menganalisis masalah-masalah sebelum membuat suatu keputusan dan mengolah keputusan yang telah dibuat, sehingga menghasilkan pertimbangan masalah serta alternatif penyelesaian yang lebih saksama. Oleh karena itu, karakteristik gender pada perempuan lebih memberikan pendapat yang lebih meluas terkait makna CSR pada perusahaan PT.SUB dengan hati dan pemikiran yang sudah dipertimbangkan. Menurut Kusumastuti (2008) dalam Hadya \& Susanto (2018) mengungkapkan bahwa wanita memiliki sikap kehati-hatian yang sangat tinggi, cenderung menghindari risiko, dan lebih teliti dibandingkan pria. Sisi inilah yang membuat wanita tidak terburu-buru dalam mengambil keputusan, sehingga dengan adanya wanita dalam jajaran dewan perusahaan dikatakan dapat membantu mengambil keputusan yang lebih tepat dan berisiko lebih rendah.

\subsection{CSR sebagai Shodaqoh}

Tanggung jawab sosial perusahaan merupakan sebuah konsep yang berhubungan, namun perusahaan terhadap Corporate Social Responsibility (CSR) memiliki makna berbeda. Pihak manajemen PT SUB pada wawancara bahwa pelaksanaan CSR merupakan suatu amalan Shodaqoh. Pada wawancara oleh salah satu pihak internal perusahaan menyatakan:

"Perusahaan ini kan yang awalnya menjadi pro dan kontra perusahaan harus mengeluarkan dana untuk CSR agar perusahaan merasa nyaman saat melakukan kegiatan operasional, ya alhamdulillah dengan adanya CSR saya merasa itu saya anggap seperti amal atau shodaqoh, jadi ya kita harus ikhlas demi perkembangan perusahaan dan kemajuan masyarakat sekitar karena adanya CSR ini"

Dari hasil wawancara tersebut bahwa CSR dianggap seperti Shodaqoh dimana yang menyatakan adalah seorang muslim yang ingin memberikan sebagian hasilnya yaitu melalui program CSR kepada pihak yang membutuhkan yaitu masyarakat. Pengertian shodaqoh sendiri adalah menginfakkan atau memberikan sebagian hartanya dijalan Allah SWT, baik ditujukan kepada fakir miskin, kerabat, keluarga, maupun untuk kepentingan jihad fi sabilillah. Makna shodaqoh juga tercantum pada ayat-ayat Al-qur'an pada surat Al-Baqarah (2): 264 dan Al-Taubah (9): 60. Hal ini sesuai dengan ajaran islam dan tercantum dalam rukun islam Zakat. 
Zakat memiliki instrumen lainnya yaitu infak dan shodaqoh. Melalui pengumpulan instrumeninstrumen ini dapat dibangun masyarakat yang sejahtera.

Berdasarkan penjelasan di atas dapat disimpulkan bahwa perusahaan mengeluarkan CSR secara ikhlas untuk mensejahterakan masyarakat sekitar. Selain perusahaan ingin mensejahterakan masyarakat sekitar, perusahaan juga berupaya untuk menurunkan tingkat pengangguran dan kemiskinan masyarakat. Perusahaan bertanggung jawab kepada masyarakat sekitar perusahaan dan pemilik perusahaan juga bertanggung jawab atas kepemilikan perusahaannya kepada stakeholder dan Allah SWT, dengan adanya CSR masyarakat secara tidak langsung juga mendapatkan dampak positif. CSR dilakukan untuk masyarakat karena secara tidak langsung, masyarakat sekitar terkena dampak dari kegiatan operasional perusahaan.

Dalam teori legitimasi mengatakan bahwa legitimasi organisasi dapat dilihat sebagai sesuatu yang diberikan masyarakat kepada perusahaan dan sesuatu yang diinginkan atau dicari perusahaan dari masyarakat. Dengan demikian, legitimasi merupakan manfaat atau sumberdaya potensial bagi perusahaan untuk bertahan hidup (going concern) O'Donovan (2002) dalam Hadi (2010). Hal ini dapat dilihat bahwa perusahaan memberikan shodaqoh kepada masyarakat dan perusahaan mendapatkan kebebasan dalam melakukan kegiatan operasionalnya secara bebas tanpa ada gangguan dari masyarakat itu sendiri.

Berdasarkan uraian di atas dapat disimpulkan bahwa perusahaan memberikan shodaqoh untuk kepentingan perusahaan itu sendiri dan untuk kepentingan masyarakat luas. Karena perusahaan juga ingin melakukan kegiatan operasional tanpa ada gangguan dari pihak eksternal yaitu masyarakat. Dengan adanya gangguan masyarakat akan merugikan perusahaan. Perusahaan sendiri menginginkan hasil yang maksimal dalam kegiatan operasi tanpa ada gangguan yang menyebabkan proses operasional tersebut terganggu.

Berdasarkan pada hasil penelitian ini, peneliti menemukan suatu makna CSR yaitu CSR sebagai Shodaqoh. Salah satu informan pada penelitian ini mengungkapkan bahwa CSR adalah suatu amal atau shodaqoh kepada seseorang yang tidak mampu atau yang memerlukan bantuan dalam hal ini adalah masyarakat sekitar perusahaan. Informan tersebut merupakan bergender perempuan dan informan tersebut juga merupakan pemeluk agama Islam. Oleh karena itu, informan tersebut memiliki pemikiran dan pendapat bahwa CSR merupakan suatu alat untuk bersedekah atau beramal, tidak hanya patuh terhadap peraturan pemerintah saja yang diwajibkan melainkan patuh kepada yang maha kuasa yaitu Allah SWT karena bershodaqoh adalah perintah Allah SWT yang harus wajib dijalankan semua umatnya. Dasar kesetaraan antara laki-laki dan perempuan seperti ditegaskan Allah SWT. Dalam QS An-Nahl: 97 yang artinya:

"Barangsiapa mengerjakan amal saleh, baik laki-laki maupun perempuan dalam keadaan beriman, maka sesungguhnya akan Kami berikan kepadanya kehidupan yang baik dan sesungguhnya akan Kami berikan balasan kepada mereka dengan pahala yang lebih baik dari apa yang telah mereka dengan pahala yang lebih dari apa yang telah mereka kerjakan".

Berdasarkan penelitian ini dan didukung dari penelitian terdahulu bahwa keberadaan pegawai atau staff dengan karakteristik gender yang berbeda mempunyai perbedaan persepsi antara laki-laki dan perempuan. Hal tersebut dapat dilihat dari pendapat jawaban setiap informan yang berbeda. Namun dari perbedaan tersebut peneliti dapat mengetahui bahwa 
pegawai atau staff perusahaan di PT.SUB memiliki tujuan yang sama yaitu mampu menjalankan dan memaksimalkan program-program CSR di perusahaan dengan sebaikbaiknya, demi mencapai kewajiban melaksanakan tanggung jawab perusahaan dimata stakeholder atau lebih tepatnya pemerintah dan masyarakat sekitar perusahaan. Penelitian yang dilakukan Handajani, Subroto, dkk (2014) dalam Hadya dan Susanto (2018) menyatakan bahwa variasi gender berpengaruh terhadap peningkatan pengungkapan Corporate social responsibility, di dalam hasil penelitian tersebut terlihat baik laki-laki atau perempuan yang menduduki posisi sebagai dewan direksi sama-sama berorientasi untuk melakukan pengembangan Corporate Social Responsibility. Keadaan tersebut menunjukan bahwa setiap individu yang dibedakan atas gender sama-sama telah memiliki kesadaran yang tinggi untuk benar-benar melaksanakan pengungkapan Corporate Social Responsibility.

Pada saat ini gender bukanlah menjadi pembeda yang mempengaruhi pengungkapan Corporate Social Responsibility. Baik laki-laki atau wanita pada saat ini telah sama-sama memiliki kesadaran yang kuat untuk melakukan pengungkapan Corporate Social Responsibility. Keadaan tersebut menunjukan bahwa setiap individu yang dibedakan atas gender sama-sama telah memiliki kesadaran yang tinggi untuk benar-benar melaksanakan pengungkapan Corporate Social Responsibility pada perusahaan Hadya \& Susanto (2018).

\section{Simpulan}

Melalui studi kesadaran fenomenologi transendental, peneliti telah menggali kesadaran informan mengenai makna CSR. Berdasarkan hasil analisis data yang dilakukan dan juga menemukan makna-makna dalam beberapa temuan.

Berdasarkan hasil yang didapat dari penelitian yang dilakukan di PT.SUB Jombang ada beberapa kesimpulan yang bisa diambil, yaitu: 1) CSR dimaknai sebagai kepatuhan terhadap peraturan pemerintah. Pemerintah telah membuat peraturan yang berkaitan dengan pelaksanaan CSR, peraturan memang dibuat untuk ditaati, hal tersebut yang menjadi dasar pihak manajemen PT.SUB Jombang dalam memaknai CSR. Melalui peraturan yang telah dibuat oleh pemerintah, perusahaan telah diberi kepercayaan oleh pemerintah untuk melaksanakan CSR dengan baik. 2) CSR dimaknai sebagai kesadaran perusahaan terhadap masyarakat. Berawal dari suatu kewajiban, persepsi, dan pemikiran yang secara samar-samar didasari oleh individu-individu menganggap bahwa CSR memang wajib dilakukan. Dari persepsi dan pemikiran yang dilakukan akhirnya membentuk suatu kesadaran yang memang tumbuh dari dalam diri informan. Manajemen PT.SUB Jombang telah menyadari bahwa tugas perusahaan tidak hanya untuk mendapatkan laba yang sebesar-besarnya. Tetapi perusahaan juga memiliki tugas untuk memajukan masyarakat sekitar serta komitmen terhadap masyarakat dikarenakan secara tidak langsung perusahaan tumbuh dan berkembang dalam tengah-tengah kehidupan masyarakat dan dukungan dari masyarakat sekitar. 3) CSR dimaknai sebagai shodaqoh. Selain merupakan suatu kesadaran yang lebih bersifat patuh kepada Tuhan yang maha kuasa dan merupakan kesadaran suatu kewajiban khusus untuk membantu masyarakat yang kurang mampu dan membutuhkan.

Peneliti menyadari bahwa masih banyak terdapat beberapa keterbatasan dalam penelitian ini antara lain: 1) Beberapa informan hanya memberikan pendapat yang singkat dan sulit untuk dipahami dan tidak menutup kemungkinan responden tidak memahami pertanyaan yang diajukan oleh peneliti sehingga jawaban yang diberikan kurang signifikan. 2) Adanya keterbatasan waktu dalam pengambilan data yang ditentukan oleh perusahaan hanya 
14 hari, hal ini memungkinkan adanya makna yang belum terungkap secara komprehensif dan menyeluruh dalam penelitian ini. Kecukupan waktu merupakan nilai penting dalam penelitian kualitatif. Terbatasnya waktu yang dimiliki oleh peneliti sehingga peneliti hanya melakukan penelitian terhadap 3 informan untuk dijadikan subjek penelitian. 3) Beberapa informan yang dianggap sangat berpengaruh dalam penelitian ini tidak dapat ditemui seperti dewan komisi direktur, direktur dan general manajer sehingga dirasa data yang diperoleh kurang signifikan. Karena para informan tersebut sangat berpotensi terkait CSR perusahaan.

Berdasarkan hasil penelitian yang dilakukan, penulis mengajukan beberapa saran yang diharapkan dapat digunakan sebagai bahan pertimbangan. 1) Untuk Manajemen PT.SUB Jombang. Penerapan CSR pada PT.SUB sudah cukup baik, CSR sangat bermanfaat untuk masyarakat dan dapat meningkatkan image perusahaan. Jadi, seharusnya dunia usaha tidak memandang CSR sebagai suatu tuntutan represif dari masyarakat, melainkan sebagai kebutuhan dunia usaha. Untuk melaksanakan CSR perusahaan harus mengakui bahwa permasalahan masyarakat adalah milik mereka juga. Tidak hanya itu, perusahaan juga harus bersedia menanganinya. Itu dasarnya untuk melaksanakan CSR. Jadi hanya dengan mengakui masalah apa yang ada di masyarakat dan itu menjadi bagian mereka, maka CSR lebih mudah dilakukan. Sebab suatu rencana strategis dalam program-program CSR bisa jadi akan memberi kontribusi bagi pengurangan kemiskinan dan ketidakadilan sosial di Republik ini. 2) Untuk Peneliti Selanjutnya. Dalam penelitian ini telah dihasilkan makna CSR dalam perspektif PT.SUB, namun peneliti merasa masih perlu adanya penyempurnaan. Objek penelitian merupakan SWASTA yang dalam melaksanakan CSR masih dibatasi dan didasari oleh peraturan UndangUndang No. 40 Tahun 2007 tentang Perseroan Terbatas. Oleh karena itu, diharapkan penelitian selanjutnya dapat melakukan uji coba atas model ini pada perusahaan BUMN yang memiliki kebijakan sendiri dalam pelaksanaan CSR. Dengan hal ini diharapkan mampu menggali nilainilai CSR sehingga dapat menyempurnakan model yang sudah ada. Penulis juga menyarankan untuk melakukan uji coba terhadap perusahaan menengah kebawah (UKM) yang juga memiliki persepsi yang berbeda dengan perusahaan SWASTA maupun BUMN. Peneliti selanjutnya diharapkan untuk melakukan penelitian yang lebih meluas, dan lebih mendalam, diharapkan menambahkan persepsi dari masyarakat dan perusahaan. Sehingga hasil yang diperoleh lebih mendalam terhadap esensi dan makna tentang CSR. Peneliti juga menyarankan mengenai Beberapa informan yang dianggap sangat berpengaruh dalam penelitian ini tidak dapat ditemui seperti dewan komisi direktur, direktur dan general manajer sehingga dirasa data yang diperoleh kurang signifikan. Karena para informan tersebut sangat berpotensi terkait tentang CSR perusahaan. Diharapkan untuk peneliti selanjutnya melakukan wawancara kepada petinggi-petinggi perusahaan karena hal tersebut sangat berpengaruh terhadap hasil yang akan didapatkan. Peneliti juga menyarankan untuk waktu observasi penelitian kurang lebih 3 bulan demi mendapatkan hasil yang maksimal dan bisa menggali informasi lebih dalam lagi sehingga mendapatkan hasil yang signifikan dan memunculkan makna- makna baru terkait CSR disetiap perusahaan yang akan diteliti.

\section{Daftar Rujukan}

Ahmadi, R. (2014). Metodologi Penelitian Kualitatif. Yogyakarta: Ar-Ruzz Media.

Asshiddiqie, J. (2015). Gagasan konstitusi sosial: institusionalisasi dan konstitusionalisasi kehidupan sosial masyarakat madani. LP3ES.

Azheri, B. (2011). Corporate social responsibility: Dari voluntary menjadi mandatory. RajaGrafindo Persada.

Bungin, B. (2007). Penelitian Kualitatif: Komunikasi. Ekonomi, Kebijakan Publik, dan Ilmu social, Jakarta: Kencana Prenama Media Group. 
Davis, K. (1960). Iron Law of Social Responsibility.

Elkington, J. (2013). Enter the triple bottom line. In The triple bottom line (pp. 23-38). Routledge.

Ghozali, I., \& Chariri, A. (2007). Teori Akuntansi. Semarang: Badan Penerbit Universitas Diponegoro.

Gudono, G. (2014). Teori Organisasi. Yogyakarta: BPFE.

Hadi, N. (2010). Corporate Social Responsibility. Yogyakarta: Graha Ilmu.

Hadya, R., \& Susanto, R. (2018). Model hubungan antara keberagaman gender, pendidikan dan nationality dewan komisaris terhadap pengungkapan corporate social responsibility. Jurnal Benefita, 3(2), 149160.

Irawan, D. (2012). Pendekatan Institusional dalam Merumuskan Kebijakan Publik (Sebuah Kajian Teoritis).

Isa, M. A., \& Muhammad, S. (2015). The Impact of Board Characteristics on Corporate Social Responsibpility Disclosure: Evidence from Nigerian Food Product Firms. International Journal of Management Science and Business Administration, 1(12), 34-45.

ISO. (2009). Draft Internasional Standar ISO 26000: Guidance on Social Responsibility.

Kamayanti, A. (2016). Metodologi Penelitian Kualitatif. Seminar Metodologi Penelitian, Universitas Widyagama, Malang, 12 November.

Kartini, D. (2009). Corporate Social Responsibility: Transformasi Sustainability Management dan Implementasi di Indonesia. Bandung: PT. Refika Aditama.

Kusumastuti, R. D. (2008). Pengaruh Pengalaman, Komitmen Profesional, Etika Organisasi dan Gender Terhadap Pengambilan Keputusan Etis Auditor.

Kuswarno, E. (2009). Metodologi Penelitian Komunikasi Fenomenologi Konsepsi, pedoman dan contoh penelitian. Bandung: Widya Padjadjaran.

Lako, A. (2011). Dekontruksi CSR \& Reformasi Paradigma Bisnis dan Akuntansi. Jakarta: Erlangga.

Listyawati, P. R. (2016). Kajian Filosofis berparadigma Positivisme: Pelaksanaan Corporate Social Responsibility sebagai Kewajiban menurut Undang-Undang dalam Mewujudkan Good Corporate Governance. Jurnal Pembaharuan Hukum, 3(2), 237-244.

Maharani, A. (2016). Corporate Social Responsibility dan Permasalahannya (Study Kasus pada PT. X di Jawa Timur).

Moleong, L. J. (2012). Metodologi Penelitian Kualitatif. Bandung: PT. Remaja Rosdakarya.

Mulawarman, A. D. (2010). Integrasi Paradigma Akuntansi: Refleksi atas Pendekatan Sosiologi dalam Ilmu Akuntansi. Jurnal Akuntansi Multiparadigma, 1(1), 155-171.

Meyer, J. W., \& Rowan, B. (1977). Institutionalized organizations: Formal structure as myth and ceremony. American journal of sociology, 83(2), 340-363.

Naraduhita, D. C., \& Sawarjuwono, T. (2012). Corporate social responsibility: upaya memahami alasan dibalik pengungkapan CSR bidang pendidikan. Jurnal Akuntansi dan Auditing, 8(2), 95-108.

Narsa, I. M., \& Irwanto, A. (2015). Implementasi Tanggung Jawab Sosial PT. Petrokimia Gresik pada Masyarakat Lokal: Apa Kata Mereka? Jurnal Akuntansi Multiparadigma, 5(3), 450-465.

Oktarizal, M. A., Triyuwono, I., \& Achsin, M. (2014). Makna Corporate Social Responsibility Bagi Manajemen Pabrik Gula PT Kebun Agung (Malang, Jawa Timur). Jurnal Aplikasi Manajemen, 12(1), 22-31.

Paranoan, N. (2015). Riset Non Positivistik Akuntansi dalam Tiga Paradigma: Interpretif, Kritis dan Postmodernisme. Jurnal Ilmiah Akuntansi dan Bisnis, 10(1), 8-18.

Pujiningsih, S. (2008). Akuntansi Sosial. Malang: LP3. Universitas Negri Malang.

Purhantara, W. (2010). Metodologi Penelitian Kualitatif untuk Bisnis. Yogyakarta: Graha Ilmu.

Purwanto, A. (2011). Pengaruh tipe industri, ukuran perusahaan, profitabilitas, terhadap corporate social responsibility. Jurnal Akuntansi dan Auditing, 8(1), 12-29.

Rasyid, A., Saleh, A., Cangara, H., \& Priatna, W. B. (2015). Komunikasi dalam CSR Perusahaan: Pemberdayaan Masyarakat dan Membangun Citra Positif. Mimbar: Jurnal Sosial dan Pembangunan, 31(2), 507-518.

Rejeki, S. (2012). Teori Institutional (institutionalism).http://srirejekiblog-oke.blogspot.com/2012/01/akuntansi-manajemen.html diakses 23 Desember 2018 
Jurnal Ekonomi, Bisnis dan Pendidikan, 1(4), 2021, 323-343

Rismawati, R. (2015). Memaknai Program Corporate Social Responsibility: Suatu Kajian Proses Transformasi Sosial Berbasis Kearifan Lokal. Jurnal Akuntansi Multiparadigma, 6(2), 245-253.

Roen, F. (2011). Teori Institusional (Institutional Theory). Dipetik 4 Agustus 2011.

Satyaningsih, P., Atmaja, A. T \& Hermawati, N. T. (2015). Penerapan Corporate Social Responsibility pada Entitas Bisnis. Jurnal Akuntansi Program S1, 3(1): 1-11.

Scott, R. W. (2008). Institutions and Organizations: Ideas an Interest Los Angeles, London, New Delhi, Singapore. Sage Publication.

Siswoyo, H. B. B. (2012). Implementasi Corporate Social Responsibility (CSR) Urgensi dan permasalahannya. Malang: Universitas Negri Malang.

Sudiana, n. (2015). Pentingnya csr bagi perusahaan. https://www.kompasiana.com/nsudiana/pentingnya-csrbagi- perusahaan-5500c1698133115318fa7c6b diakses 13 maret 2018

Susanto, A. B. (2008). Reputation-Driven Corporate Social Responsibility, Pendekatan Strategic Managemen dalam CSR. Jakarta: Erlangga.

Untung, B. H. (2008). Corporate Social Responsibility. Jakarta: Sinar Grafika.

Undang-Undang Nomer 40 Tahun 2007 tentang Perseroan Terbatas, (Online). (http://www.ojk.go.id/sustainable.finance/id/peraturan/undangundang/Pages/Undang-Undang-No.-40-tahun-2007tentang- PerseroanTerbatas.aspx), diakses 26 Mei 2018.

Undang-Undang Nomor 25 Tahun 2007 tentang Penanaman Modal, (Online). (http://www.ojk.go.id/sustainable.finance/id/peraturan/undangundang/Pages/Undang-Undang-No.-25-Tahun-2007tentang-PenanamanModal.aspx), diakses 26 Mei 2018.

Undang-Undang Nomor 23 Tahun 1997 tentang Pengolahan Lingkungan Hidup, (Online). (http://www.ojk.go.id/sustainable.finance/id/peraturan/undang-undang/Pages/Undang-UndangNo.-25-Tahun-2007- tentang.PenanamanModal.aspx), diakses 26 Mei 2018.

Universitas Negeri Malang. (2017). Pedoman Penulisan Karya Ilmiah: Skripsi, Tesis, Disertasi, Artikel, Makalah, Tugas Akhir, Laporan Penelitian. Malang: Universitas Negri Malang.

Wibisono, D. (2003). Riset Bisnis, Jakarta: PT. Gramedia Pustaka Utama.

Zucker, L. G. (1987). Institutional Theories of Organization. Annual Reviews Social, 13. 443-464. 